\title{
Checkpoint inhibitors in endometrial cancer: preclinical rationale and clinical activity
}

\author{
Gloria Mittica ${ }^{1,2, *}$, Eleonora Ghisoni ${ }^{1,2, *}$, Gaia Giannone ${ }^{1,2}$, Massimo Aglietta ${ }^{1,2}$, Sofia \\ Genta $^{1,2}$ and Giorgio Valabrega ${ }^{1,2}$ \\ ${ }^{1}$ Department of Oncology, University of Turin, Turin, Italy \\ ${ }^{2}$ Division of Medical Oncology-1, Candiolo Cancer Institute-FPO- IRCCS, Candiolo, Italy \\ *These authors contributed equally to this work \\ Correspondence to: Giorgio Valabrega, email: giorgio.valabrega@ircc.it \\ Keywords: endometrial cancer, immunotherapy, tumor infiltrating lymphocytes (TILs), polymerase epsilon (POLE)-ultra-mutated, \\ microsatellite instability (MSI)
}

Received: June 08, $2017 \quad$ Accepted: July 26, $2017 \quad$ Published: August 08, 2017

Copyright: Mittica et al. This is an open-access article distributed under the terms of the Creative Commons Attribution License 3.0 (CC BY

3.0), which permits unrestricted use, distribution, and reproduction in any medium, provided the original author and source are credited.

\section{ABSTRACT}

Context: Treatment of advanced and recurrent endometrial cancer (EC) is still an unmet need for oncologists and gynecologic oncologists. The Cancer Genome Atlas Research Network (TCGA) recently provided a new genomic classification, dividing EC in four subgroups. Two types of EC, the polymerase epsilon (POLE)-ultra-mutated and the microsatellite instability-hyper-mutated (MSI-H), are characterized by a high mutation rate providing the rationale for a potential activity of checkpoint inhibitors.

Materials and Methods: We analyzed all available evidence supporting the role of tumor microenvironment (TME) in EC development and the therapeutic implications offered by immune checkpoint inhibitors in this setting. We performed a review on Pubmed with Mesh keywords 'endometrial cancer' and the name of each checkpoint inhibitor discussed in the article. The same search was operated on clinicaltrial. gov to identify ongoing clinical trials exploring PD-1/PD-L1 and CTLA-4 axis in EC, particularly focusing on POLE-ultra-muted and MSI-H cancer types.

Results: POLE-ultra-mutated and MSI-H ECs showed an active TME expressing high number of neo-antigens and an elevated amount of tumor infiltrating lymphocytes (TILs). Preliminary results from a phase-1 clinical trial (KEYNOTE-028) demonstrated antitumor activity of Pembrolizumab in EC. Moreover, both Pembrolizumab and Nivolumab reported durable clinical responses in POLE-ultra-mutated patients.

Conclusions: Immune checkpoint inhibitors are an attractive option in POLEultra-mutated and MSI-H ECs. Future investigations in these subgroups include combinations of checkpoints inhibitors with chemotherapy and small tyrosine kinase inhibitors (TKIs) to enhance a more robust intra-tumoral immune response.

\section{INTRODUCTION}

Endometrial Cancer (EC) is expected to be the 4th most common malignancy among women and the 6th leading cause of death in 2017 [1]. EC is frequently associated with Lynch Syndrome (LS). also called hereditary non-polyposis colon cancer (HNPCC), [2], an autosomal dominant genetic disorder which confers an increased risk of developing different kind of tumours, [3].
LS, is characterized by alterations in genes involved in DNA mismatch repair (MMR), such as MLH1, MSH2, MSH6, PMS2 and EPCAM, resulting in microsatellite instability (MSI) [4]. For the $67 \%$ of EC patients diagnosed at an early stage, 5 -year overall survival is of $95 \%$ after surgery with or without radiotherapy. Instead EC patients diagnosed at a late stage have a 5 -year survival rate of only $17 \%[1,5]$; these patients are candidate to systemic treatment with 
palliative intent, including chemotherapy, among which carboplatin-paclitaxel doublet is the most effective scheme [1], and endocrine treatments [6]. Up to date there is no standard second line therapy [7].

In this review, we will concentrate on the scientific background supporting the clinical development of immune checkpoint inhibitors in advanced and recurrent disease with a specific focus on the role of tumor microenvironment (TME).

\section{The "modern" molecular classification: beyond Bokhman's dual scheme}

$\mathrm{EC}$ is an heterogeneous disease with various histological subtypes, which have different pathogenesis, prognosis and sensitivity to different therapeutic agents [8].

In the past decades, EC has been classified in two subtypes, respectively named Type I and Type II according to Bokhman's model [9], based on clinical characteristics integrated with histological features and hormone receptor (HR) status. Type I is the most common EC $(60-70 \%$ of cases); it includes grade 1 and 2 endometrioid cancer with a high presence of Estrogen Receptors (ERs) and Progesteron Receptors (PgRs). It is related to increased Estrogen levels and endometrial hyperplasia and it is usually associated with a good prognosis (median 5-year survival rates of $85.6 \%$ ). The most frequently altered pathway in Type I is PTEN$\mathrm{PIK} 3 / \mathrm{AKT} / \mathrm{mTOR}$ (PTEN is mutated in approximately 52$78 \%$ of lesions), followed by KRAS mutations (15-43\%), ARID1 A and B-catenin alterations [10]. MSI is present in one third of type I EC [11].

Type II EC comprises Grade 3 endometrioid, serous or clear cell HR negative cancers, and it is usually associated with endometrial atrophy [12]. TP53 is the hallmark alteration of this subtype. Patients with type II EC generally show an advanced stage at diagnosis, a low response rate to therapies and a poor prognosis $[11,12]$.

This dualistic model has recently been expanded in consideration of new knowledge concerning genomic and transcriptomic analysis [13, 14]. In 2013 TGCA (The Cancer Genome Atlas Research Network) [14] published the first genomic characterisation of EC. Results of this study allowed EC classification in four different subtypes, based on somatic mutations, copy number alterations and microsatellite instability:

POLE-ultra-mutated malignancies, representing $6.4 \%$ of low-grade and $17.4 \%$ of high-grade endometrioid tumours, are characterized by a high mutation rate $\left(232 \times 10^{-6}\right.$ mutations $\left./ \mathrm{Mb}\right)$; their hallmarks are somatic mutations in the exonuclease domain of POLE that encodes the catalytic subunit of DNA polymerase epsilon. Loss of function of this polymerase, which plays a relevant role in DNA repair, leads to a high frequency of $\mathrm{C}>\mathrm{A}$ transversions, few copy number alteration and microsatellite stability (MSS). PTEN, PIK3R1, PIK3CA, RAS are frequently mutated $[12,14,15]$. Despite the histological grade, this group is associated with good prognosis [16-20].

MSI-hyper-mutated (MSI-H) tumors represent $28.6 \%$ of low grade and $54.3 \%$ of high-grade endometrioid EC [14, 15, 21]. They show MSI and high mutation rate $\left(18 \times 10^{-6}\right.$ mutations $\left./ \mathrm{Mb}\right)$ related to defects in MMR system (the most implicated genes are MLH1, MSH2, MSH6, PMS2), both in sporadic and hereditary EC. PTEN mutations and subsequent alterations of the PTENPIK3CA pathway recur in this subgroup [22]. Further genetic abnormalities are frequent, like RPL22 frameshift deletions and KRAS mutation. There is no significant correlation between MSI and outcome in ECs patients [23].

Copy-number low EC is characterized by a low mutation rate $\left(2.9 \times 10^{-6}\right.$ mutations/Mb) and MSS. It is frequently a low-grade endometrioid cancer (in TGCA $60 \%$ of low-grade and only $8.7 \%$ of high grade EC were MSS copy low); PTEN and PIK3CA are mutated in 77\% and $53 \%$ of cases respectively $[14,15]$. Other common alterations involve WNT-B catenin axis; RAS mutation is rare; $\mathrm{PgR}$ levels are high and this finding predicts usefulness of endocrine therapy [21, 24]. Prognosis is similar to MSI-H tumors without a clear correlation between this subtype and clinical outcome.

Copy-number high serous like subgroup includes mainly serous and mixed histology tumors with some high grade endometrioid EC. It has a low mutation rate $\left(2.3 \times 10^{-6}\right.$ mutations/Mb) and a small load of copy number aberrations. TP53 is commonly mutated (92\%), whereas KRAS and PTEN mutation are infrequent; $25 \%$ of the serous-like tumours are ERBB2-amplified [14, 21]. Prognosis of these patients is poor $[12,15]$.

This new classification, reported in Figure 1, could be comparable to the already well known pathogenesis model of colon-rectal cancer [25] and may represent a step forward in defining prognosis of EC patients and may help in improving clinical trial design with targeted agents $[24,26,27]$.

As recently reported, normal endometrium has a peculiar immune system; indeed, it has a dualistic role: it should be active against sexual pathogens and should allow the growth of an allogenic and "non-self" fetus $[28,29]$. This behavior is regulated by sex hormones that influence therefore the TME, especially defining the typology of adaptive immune cells [30].

It is well known that immune cells can recognize and eliminate cancer cells through the identification of tumor-specific antigens (TSA) and tumor-associated antigens (TAA) [31].

Physiologically, when TAA are recognized by $\mathrm{T}$ cells they are handled, converted into small fragments and finally presented by antigen-presenting cells (APCs) after loading on major histocompatibility complex (MHC) class I and II. Usually, immune response activation is elicited if two positive signals are present. The first one is the interaction between MHC molecules and $\mathrm{T}$ cell 
receptors (TCR); the second one is the connection of the co-stimulatory receptor CD28, present on $\mathrm{T}$ cells' surface, with its ligand B7 on APCs. In order to avoid autoimmune reaction $\mathrm{CD} 28$ has a competitor for binding B7, the cytotoxic T lymphocyte antigen-4 (CTLA-4), which carries an inhibitory signal. This negative feedback is mostly represented within secondary lymphoid organs, while the inhibitory pathway more frequently present within peripheral TME is the connection between the programmed cell death-1 (PD-1) receptor on the $\mathrm{T}$ cells, and the programmed cell death ligand-1 and 2 (PD-L1 and PD-L2) on the tumor cells surface [32, 33]. Different molecular patterns are involved downstream this interaction, such as inhibition of PI3K/AKT and Ras/ MEK/Erk pathways, through down-regulation of PTEN and PLC- $\gamma 1$ respectively [34-36] (Figure 2). Inflammatory cytokines, as interferon, IL-4 and IL-10, generated after recognition of TAA and TSA stimulates PD-1 and PDL1 over-expression, lead to down-regulation of T-cell reaction and create the mechanism called "adaptive immune resistance" [37]. Other immune checkpoints seem to play a role in adaptive immune resistance, such as Lymphocyte Activation Gene 3 (LAG-3) and indoleamine 2,3-dioxygenase (IDO), both up-regulated in POLE and MSI-H subtypes [38, 39]. Among gynecological cancer, EC show the highest expression of PD-1 and PD-L1,75\% and $25-100 \%$ respectively [40]. Moreover, Vanderstraeten and coll. analyzed other immune-related molecules and reported that $\mathrm{B} 7-\mathrm{H} 4$, responsible of another inhibitory pathway of $\mathrm{CD}^{+}$and $\mathrm{CD}^{+} \mathrm{T}$ cells, is present in $90 \%$ of EC specimens, while IDO is expressed only in $21 \%$ of EC samples [39]. These findings confirm an important role of PD-1/PD-L1 pathway and suggest B7-H4 signal as a potential new therapeutic target.

The correlation between PD-L1 expression and patient's outcome is controversial, since has been associated with a worse prognosis in some tumors, like non-small cell lung cancer (NSCLC) [41], kidney [42-44] and bladder [45] cancer, and with a good one in melanoma [46]. Currently, PD-L1 is routinely analyzed in advanced NSCLC in order to prescribe checkpoint inhibitors, even if is still controversial which is the best cut-off to define positivity and which the best antibody to detect the expression on immunohistochemistry (IHC) assay [47]. PD-L1 detection is regularly used also in the treatment of kidney and bladder cancers [48].

The prognostic value of the expression of this inhibitory pathway, as the role of other components of tumor microenvironment (TME), such as tumor infiltrating lymphocytes (TILs), is currently under investigation in EC. PD-1 and PD-L1 are more frequently reported in POLE-mutated and MSI-H tumors. This pathway might account for more aggressive histopathologic features observed in POLE-mutated, as reported above, even if these tumors have a good prognosis related to a higher number of $\mathrm{CD}^{+}$and $\mathrm{CD}^{+}$TILs that prevent disease dissemination $[49,50]$. POLE-mutated and MSI tumors have an active TME not only for the high number of TILs, but also for the huge amount of tumor specific neo-antigens, generated by genetic alteration acquired due to impaired DNA replication fidelity (POLE) and defective DNA MMR system (MSI-H) [4, 14] (Figure 3). Recent studies have characterized the different cell populations constituting TME. The presence of TILs

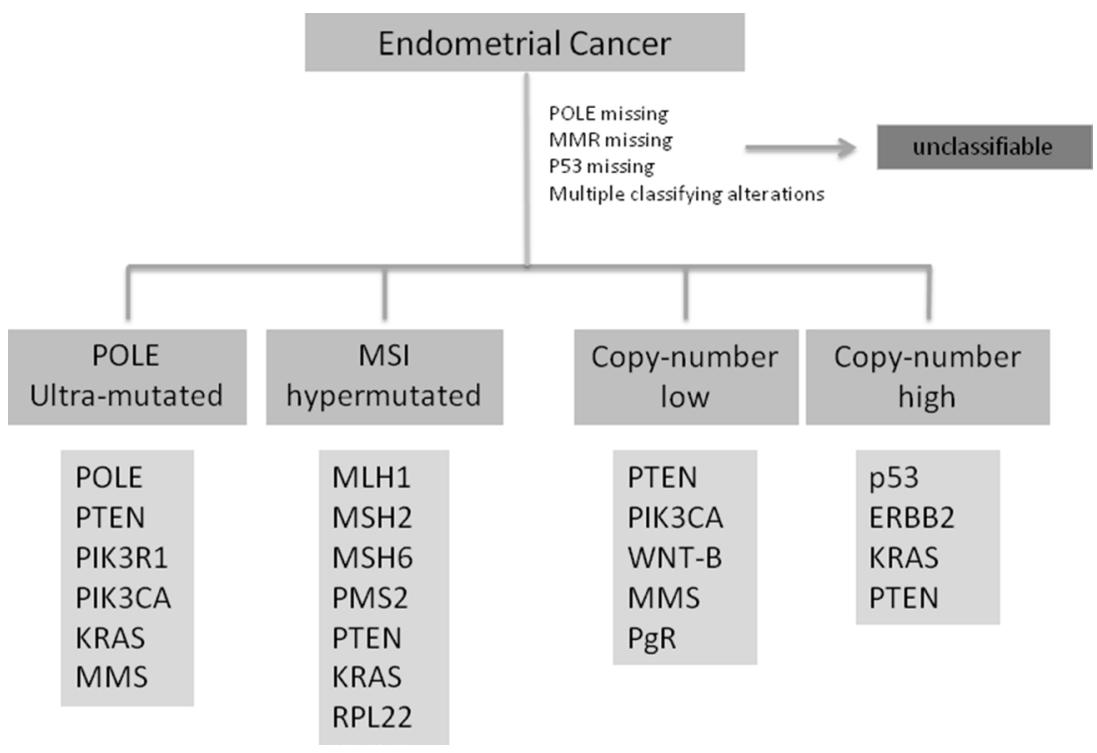

Figure 1: Shows the ECs classification according to TGCA including the most common genetic alteration in each subtype. POLE: polymerase epsilon; MMR:mismatch repair; p53: tumor protein p53; PTEN: phosphatase and tensin homolog; PIK3: phosphatidylinositol-4,5-bisphosphate 3 kinase; KRAS: Kirsten rat sarcoma viral oncogene homolog; MMS: microsatellite stability; MSI: microsatellite instability; MLH: mutL homolog 1; MSH2: mutS homolg 2; MSH6: mutS homolog 6; RPL22: 60S ribosomal protein L22; ERBB2: human receptor tyrosine-protein kinase erbB-2; WNT-B: WNT-beta catenin pathway; PgR: progesteron receptor. 
appears associated with a better outcome in many different kinds of cancers such as melanoma [51], esophageal [52], breast [53], colorectal [54] and ovarian cancer $[55,56]$. In EC, in 2009 de Jong and colleagues assessed the number of $\mathrm{CD}^{+}$(cytotoxic T-lymphocytes, $\mathrm{CTL}$ ), $\mathrm{FOXP}^{+}$(regulatory T-lymphocytes, Treg) and $\mathrm{CD}^{4} \mathrm{R} 0^{+}$(memory T-lymphocytes) TILs by IHCon tissue microarrays [57]. High numbers of CTL and a high $\mathrm{CD}^{+} /$ $\mathrm{FOXP}^{+}$ratio were correlated with a longer disease free survival (DFS), while high levels of CTL and presence of $\mathrm{CD} 45 \mathrm{R} 0^{+}$memory cells were associated with a greater overall survival (OS). In the multivariate analyses high presence of CTL was an independent prognostic factor for longer OS in the entire EC population (HR 0.48,

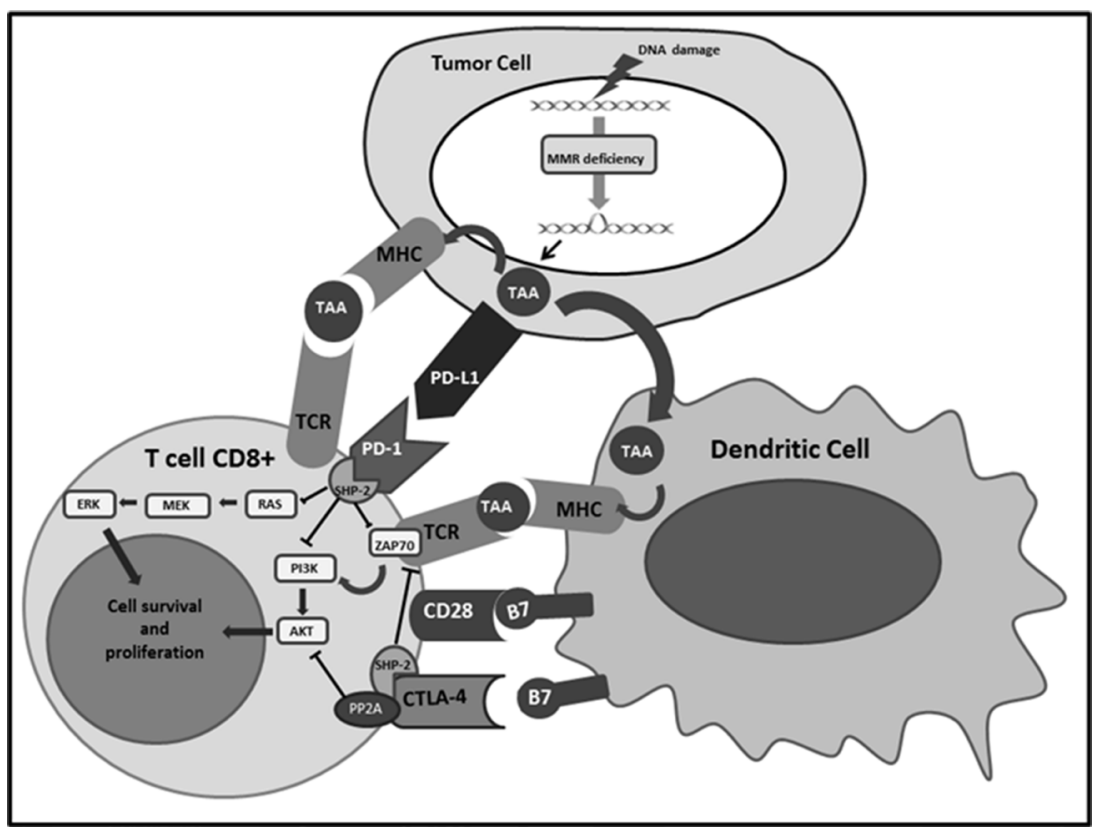

Figure 2: Shows the interactions of PD-1 and CTLA-4 expressed on the surface of the T cells with the respective ligands and the subsequent activation of immune checkpoint signalling pathways that inhibit lymphocytes survival and proliferation. CTLA-4:Cytotoxic T-Lymphocyte Antigen 4; MHC: Major histocompatibility complex; MMR: Mismatch repair PD-1: Programmed cell death protein 1; PD-L1: Programmed death-ligand 1; TAA: Tumor associated antigen ;TCR: T-cell receptor.

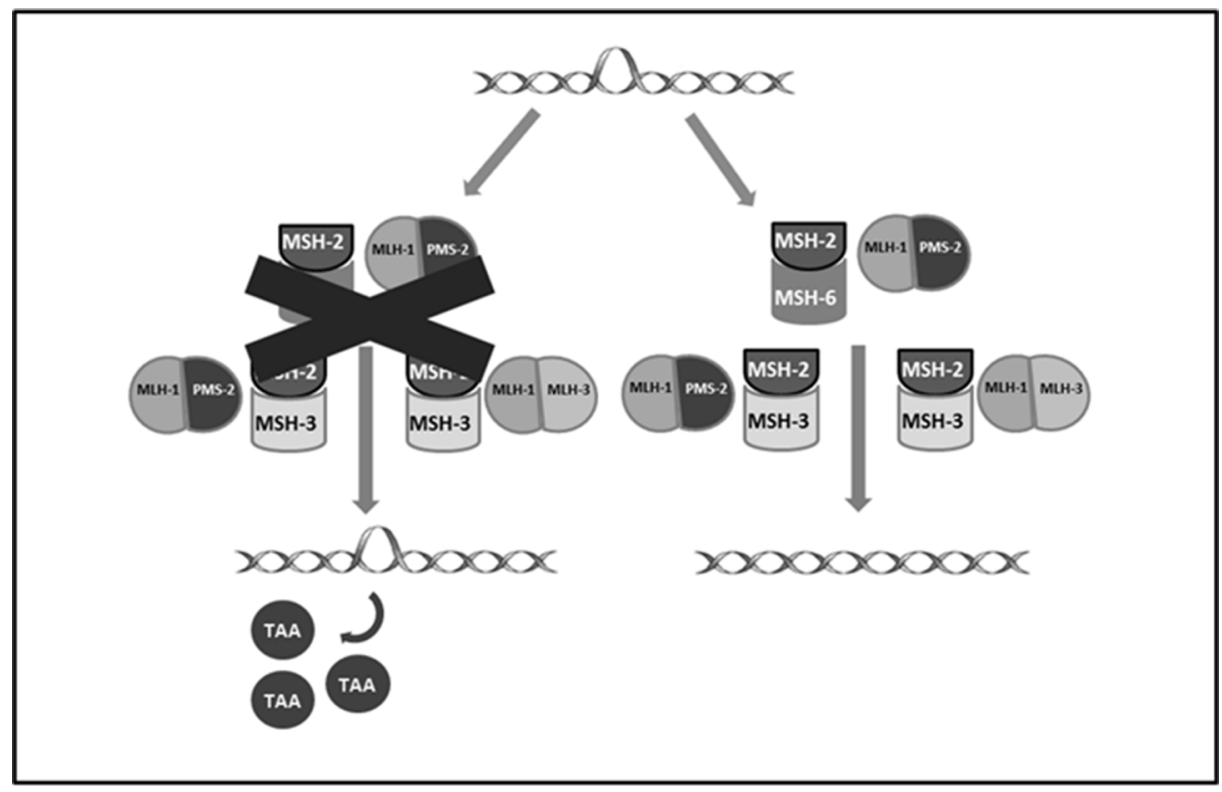

Figure 3: Shows proteins involved in DNA mismatch repair system and the formation of neoantigens resulting from their deficiency. TAA: tumor associated antigen. 
$p=0.019$ ), with a major impact in type II EC (HR 0.17, $p<0.001$ ), whereas high $\mathrm{CD}^{+} / \mathrm{FOXP}^{+}$ratio is the factor independently correlated with prolonged survival in type I cancers. The prognostic role of $\mathrm{CD}^{+} / \mathrm{FOXP}^{+}$ratio was confirmed also by subsequent investigations $[58,59]$. The studies focused on Treg alone reported a correlation with tumor stage, grade and myometrial invasion but not with survival $[60,61]$. Recently, Pakish and colleagues evaluated the EC TME matching and comparing MSI-H with MSS (POLE-mutant cases and cases with unknown POLE status were excluded) [4]. They reported an increased number of immune cells in specimens from MSI-H EC including granzyme B+ cells, activated CTL and PD-L1 + cells. The authors also compared sporadic MSI-H EC with those related to LS (LS MSI-H): they observed an increased level of CD8+ cells and activated CTL with a lower number of macrophages in stroma of LS MSI-H EC while sporadic MSI-H EC showed a higher level of PD-L1 + macrophages. The analyses performed by the TransPORTEC consortium on 116 high-risk ECs, published also in 2017, confirmed that POLE-mutant and MSI-H tumors are characterized by higher numbers of tumor-infiltrating $\mathrm{T}$ cells. These two subgroups are both neoantigen-rich and with a huge density of PD-1 and PD-L1 expression and so are the perfect candidates for immune checkpoint inhibitors, as further reported [62]. In order to avoid the activation of the inhibitory pathways described above different antibodies have been developed, targeting PD-1, PD-L1, PD-L2 and CTLA-4 These molecules, known as "checkpoint inhibitors", exhibited efficacy and durable clinical response in various cancer types and have already been approved for NSCLC [63, 64], melanoma [46, 65-69], kidney [70], bladder $[71,72]$ and Hodgkin Lymphoma $[73,74]$.

\section{Clinical activity of checkpoint inhibitors in endometrial cancer}

The first evidence for clinical activity of immunotherapy in EC derive from a phase II trial published in 2015 by Le and colleagues which enrolled 41 patients [75]. Study population was divided in three cohorts, including respectively patients with MMRdeficient colorectal cancer, patients with MMR proficient colorectal cancer and patients with MMR-deficient cancers other than colorectal cancer; in third cohort were also included two patients affected by EC. All patients were treated with the anti-PD-1 Pembrolizumab. Authors reported a higher immune-related objective response rate (ORR) and 20-week immune related progression free survival (PFS), $40 \%$ and $78 \%$, respectively, in the MMR deficiency cohorts, versus $0 \%$ and $11 \%$ in MMR proficient colorectal patients. In cohort $\mathrm{C}$, including the 2 EC patients, immune-related ORR and PFS were $71 \%$ and $67 \%$, respectively. This is a pivotal study reporting for the first time a connection between TME, genotype and response to checkpoint inhibitors, a significant step forward in the identification of predictors of response, as discussed in the next section.

Recently, Ott and colleagues published the results of KEYNOTE-028 trial, a phase Ib study involving 24 patients with advanced EC [76]. All patients were treated with Pembrolizumab $10 \mathrm{mg} / \mathrm{kg}$ every two weeks for up to 24 months or until confirmed progression, intolerable toxicity, death, or consent withdrawal. Overall Response rate observed was $13 \%$. Three patients obtained a partial response and other three achieved a stable disease. Authors reported a six-months PFS and OS rates of $19.0 \%$ and $68.8 \%$ respectively. Drug-related adverse events occurred in $54.2 \%$ of patients; most common were pruritus, asthenia, fatigue, pyrexia, and decreased appetite. No patients died or discontinued Pembrolizumab because of toxicities. Interestingly, Ganesan and collegues reported the case of a durable partial response with Pembrolizumab in one patient with POLE-mutation [77]. Pembrolizumab has been tested in metastatic EC also in combination with Lenvatinib, a multikinase-inhibitor with antiangiogenic activity. Makker and colleagues recently presented the results of a phase I / II trial in which 23 patients received Lenvatinib $20 \mathrm{mg}$ /day and Pembrolizumab $200 \mathrm{mg}$ every three weeks. The authors reported an ORR of $48 \%$ and a DCR of $96 \%$. The most common adverse events were hypertension, fatigue, arthralgia, diarrhea and nausea [78].

In 2016 Santin and colleagues reported the cases of two patients with recurrent EC refractory to surgery, chemotherapy and radiotherapy treated with the antiPD-1 Nivolumab [79]. The two women were respectively affected by a mixed clear cell and endometrioid POLE mutated EC and by a serous MSH6 mutated EC. Both patients were treated with Nivolumab $3 \mathrm{mg} / \mathrm{kg}$ biweekly. CTL infiltration and PD-L1 expression were evaluated on a pretreatment biopsy. The first patient showed a moderate amount of peri and intratumoral lymphocytic infiltrate. Moreover, a weak membranous PD-L1 expression was reported in about $5 \%$ of the tumor cells, whereas the periand intratumoral lymphocytes were PD-L1 negative. In the second patient the peri-tumoral lymphocytic infiltrate was moderate, whereas there were fewer CD8-positive lymphocytes within the tumor cell nests. PD-L1 was observed in approximately $20 \%$ of peri- and intratumoral lymphocytes, while no significant PD-L1 expression was observed for cancer cells. In this case authors evaluated also p53 expression by immune histochemistry which revealed a wild type pattern. Both patients obtained a persistent clinical response to Nivolumab confirmed by a CT scan respectively at 7 and 9 months from the start of immunotherapy. No severe toxicities were reported.

Antibodies against PD-L1 were also tested for the treatment of endometrial carcinoma.

Fleming and colleagues reported the results of a phase Ia study in which 15 women with EC received Atezolizumab $15 \mathrm{mg} / \mathrm{m} 2$ every three weeks. The majority 
of patients were MSS (7/15) or MSI unknown ( 7/1), only one patient has a MSI-H disease. Authors also evaluated the status of PD-L1: $33 \%$ of patients had an expression of PD-L1 greater than $5 \%$ on immune cells while in the remaining $67 \%$ the PD-L1 expression was lower. Two patients obtained a partial response and other two achieved a stable disease with an ORR of $13 \%$ and a DCR of $27 \%$. Both responders had an expression of PD-L1 greater than $5 \%$, one had MSS disease heavily infiltrated with TILs, the other had a MSI-H disease, moderately infiltrated with TILs. Duration of response was 7.3 and $8.1+$ months, respectively. Authors reported a median PFS of 1.7 months and a median OS of 9.6 months. Drug related severe adverse events (colitis and rash) occurred only in two patients, no G4-5 related AEs were reported [80] A Phase 2 study with an anti-PD-L1 antibody was recently presented at ASCO 2017: it is an open-label, two stage trial in which Avelumab $10 \mathrm{mg} / \mathrm{kg}$ was administered biweekly to women with recurrent or persistent endometrial cancer. Patients were divided in two cohorts on the basis of the MMR proteins expression. In the first stage, 16 patients will be enrolled in each cohort, if at least two objective responses or two PFS at six months were observed accrual will continue to the second stage. The trial is ongoing and until now 16 patients have been enrolled: 13 in the MSS cohort and 3 in the MSI/POLE cohort. Co-primary endpoints are ORR and rate of PFS at six months [81]. The results of the preliminary clinical data are summarized in Table 1.

As discussed above another possible target for checkpoint inhibitors is CTLA-4, in order to prevent binding with its ligand B7. Ipilimumab and Tremelimumab are monoclonal antibodies able to disrupt this interaction. This approach has proven to be effective in the treatment of melanoma [82, 83], but data supporting the effectiveness of anti-CTLA4 in the treatment of EC have not been reported so far.

\section{DISCUSSION AND FUTURE PERSPECTIVES}

The use of checkpoint inhibitors has a strong rationale in EC, however clinical development is at very beginning and, despite preliminary encouraging results, several issues need to be addressed.

First of all, few data are available regarding predictive biomarkers of response to checkpoint inhibitors. In order to select patients who mostly benefit from these therapies more and more studies analyze cancer genome and its correlation with TME. PD-L1 expression level has been reported as a predictive biomarker of response in NSCLC $[63,65]$ but its predictive role is not consistent across different cancers types. This may be related to various detection strategies and different specimens analyzed (before, during or after treatments) [66]. Moreover, a crucial role in immune surveillance is played by the others cells expressing PDL1 present in TME, as reported in a translational study by
Webb and colleagues for tumor-associated macrophages (TAMs) on the basis of tissue microarrays of optimally debulked ovarian cancers [84].

Recently, huge progress has been achieved regarding the relationship between cancer genome and response to checkpoint inhibitors [85, 86]. A relationship between response to $\mathrm{PD}-1 / \mathrm{PDL}-1$ inhibitors and somatic mutations load has been reported in melanoma and lung cancer $[67,68]$ according to the hypothesis that identifying neo-antigens generated by mutations is an essential step for immune response. Indeed, mutational burden defines immunogenicity of cancers $[87,88]$. Besides the neo-antigens loads, some studies were conducted in the melanoma to identify mechanisms related to resistance to PD-1 inhibitors. Shin and colleagues found that loss of function mutations in JAK1 and JAK2, where associated with a deficiency of interferons that physiologically induce PD-L1 upregulation, in several melanoma cells lines which correlate to resistance to checkpoints inhibitors. Moreover, they reported beta- 2 microglobulin deletions or mutations leading to beta-2 microglobulin inactivation and subsequent inability for $\mathrm{T}$ cells to recognize the tumor. These mutations are responsible for primary resistance or can be developed during treatment, arising secondary resistance to checkpoints inhibitors [89, 90]. The importance of the interferon associated pathways for the response to anti PD-1 and CTLA-4 was confirmed also by an MD Anderson report [91].

As reported above, two subgroups of EC, POLEultra-mutated and MSI-H, are characterized by higher number of neo-antigens and the elevated amount of TILs [15]. The consequent high immunogenicity of POLEultramutated EC is speculated to be responsible for the good prognosis and possibly for likelihood of responding to immune checkpoint inhibitors [92]. Neo-antigen load could possibly be a biomarker of response also in hypomutated EC, as reported by Shukla and colleagues [93]. Indeed they observed that hypo-mutated tumors with highest neoantigen load have a better PFS. Moreover, they reported that a lower neo-antigens number is associated with particular gene alterations, CTNNB1 and PIK3CA mutations and MYC amplifications. The above variations could be used as indicators of less immunogenicity and, consequently, of lower response rate to checkpoint inhibitors. These discoveries could help clinicians to identify EC patients that could benefit from checkpoint inhibitors.

The need to identify possible biomarkers of response is also crucial for the ongoing clinical trials, reported in Table 2, which, following evidence derived from other cancers, are exploring combinations of checkpoints inhibitors or associations of checkpoints inhibitors with chemotherapy, small tyrosine kinase inhibitors (TKIs) and mTOR inhibitors.

The study published by Pakish evaluating the immune infiltrate in MSI-H EC suggests for the first time 
Table 1: Published and preliminary data of trials evaluating the activity of checkpoint inhibitors in the treatment of endometrial cancer

\begin{tabular}{|c|c|c|c|c|c|c|c|c|}
\hline Kind of treatment & $\begin{array}{c}\text { Number of } \\
\text { patients }\end{array}$ & Phase & $\begin{array}{c}\text { Class of experimental } \\
\text { agent }\end{array}$ & Line of therapy & ORR & PFS & OS & Study name/First author \\
\hline Pembrolizumab $10 \mathrm{mg} / \mathrm{kg}$ every 2 weeks & 24 & $\mathrm{Ib}$ & Anti-PD-1 & $2 \mathrm{~L}+$ & $13 \%$ & $19 \%$ at six months & $68.8 \%$ at six months & KEYNOTE-028 \\
\hline $\begin{array}{l}\text { Lenvatinib } 20 \mathrm{mg} / \text { day }+ \text { Pembrolizumab } \\
\qquad 200 \mathrm{mg} \text { every } 3 \text { weeks }\end{array}$ & 23 & $\mathrm{Ib} / \mathrm{II}$ & $\begin{array}{l}\text { Multikinase inhibitor }+ \\
\quad \text { Anti-PD-1 }\end{array}$ & $2 \mathrm{~L}+$ & $48 \%$ & Not estimable & Not estimable & Vicky Makker \\
\hline $\begin{array}{c}\text { Atezolizumab } 1200 \mathrm{mg} \text { or } 15 \mathrm{mg} / \mathrm{kg} \\
\text { IV q3w }\end{array}$ & 15 & Ia & Anti-PD-L1 & $2 \mathrm{~L}+$ & $13 \%$ & 1.7 months & 9.6 months & Gini F. Fleming \\
\hline
\end{tabular}

PFS = Progression Free Survival; ORR = Overall Response Rate; OS = Overall Survival.

Table 2: Ongoing trialsusing checkpoint inhibitors in endometrial cancer

\begin{tabular}{|c|c|c|c|c|c|c|}
\hline Combination & Treatment setting & Line of therapy & Phase & Primaryendpoint & Status & Trial identifer \\
\hline aPD-L1 & Avelumab in Patients With MSS, MSI-H and POLE-mutated & $2 \mathrm{~L}+$ & 2 & PFS6 & Recruiting & NCT02912572 \\
\hline aPD-1 & Pembrolizumab in Ultramutated and Hypermutated EC & $2 \mathrm{~L}+$ & 2 & ORR, safety by CTCAE v 4 & Recruiting & NCT02899793 \\
\hline aPD-1 & Pembrolizumab on the TumoralImmunoprofile of Gynecologic Cancers & $1 \mathrm{~L}$ & 1 & Tumor immune infiltrates & Recruiting & NCT02728830 \\
\hline aPD-1 & MK-3475 Immunotherapy in Endometrial Carcinoma & $1 \mathrm{~L}$ & 1 & Safety by CTCAE v4 & Recruiting & NCT02630823 \\
\hline aPD-1 + Chemo & Pembro/Carbo/Taxol & $1 \mathrm{~L}+$ & 2 & ORR & Not yet recruiting & NCT02549209 \\
\hline $\mathrm{aPD}-1+\mathrm{Bev} / \mathrm{C} / \mathrm{PLD}$ & IMGN853 + Bevacizumab, Carboplatin, PLD or Pembrolizumab & $2 \mathrm{~L}+$ & 1 & ORR, SAEs, TEAEs & Recruiting & NCT02606305 \\
\hline aPD-1 + TKI & Pembrolizumab + Lenvatinib & $2 \mathrm{~L}+$ & $1 \mathrm{~b} / 2$ & MTD, DLTs, ORR & Recruiting & NCT02501096 \\
\hline aPD-1 + TIL & Pembrolizubab+ TIL PBL and aldesleukin & $2 \mathrm{~L}+$ & 2 & ORR & Recruiting & NCT01174121 \\
\hline aPD-1 + TKI & Pembrolizumab + Itacitinib & $2 \mathrm{~L}+$ & 1 & Safety by CTCAE v4 & Recruiting & NCT02646748 \\
\hline aPD-L1 + aCTLA-4 & Durvalumab $+/-$ Tremelimumab & $2 \mathrm{~L}+$ & 2 & ORR & Recruiting & NCT03015129 \\
\hline aPD-1 + Chemo & Nivolumab + Chemotherapy & $2 \mathrm{~L}+$ & $1 \mathrm{~b} / 2$ & RP2D & Recruiting & NCT02423954 \\
\hline aPD- $1+$ aCTLA-4 & Nivolumab + Ipilimumab & $2 \mathrm{~L}+$ & 2 & ORR & Not yet recruiting & NCT02982486 \\
\hline aPD-1 + mTORi & Nivolumab + Temsirolimus/ Nivolumab + CT & $2 \mathrm{~L}+$ & $1 b / 2$ & RP2D & Recruiting & NCT02423954 \\
\hline aPD-1 + aCTLA-4 & Nivolumab + Ipilimumab in rare tumors & $1 \mathrm{~L}+$ & 2 & ORR & Recruiting & NCT02834013 \\
\hline aPD-L1 + Chemo & Atezolizumab + Carboplatin-cyclophosphamide & $2 \mathrm{~L}$ & 1 & Toxicity by CTCAE v4 & Recruiting & NCT02914470 \\
\hline aPD-L1 + IDO Inhibithor & Atezolizumab + GDC-0919 & $2 \mathrm{~L}+$ & 1 & DLT, SAEs & Recruiting & NCT02471846 \\
\hline
\end{tabular}

Chemo, chemotherapy; Bev, bevacizumab; C, Carboplatin; PLD, pegylatedliposomaldoxorubicin; TKI, tyrosine-kinaseinhibitor; TIL, tumorinfiltratinglymphocytes; mTORi, mTORinhibitor; IDO, indoleamine 2,3-dioxigenase; L, line (regime of chemotherapy); PFS6, progression free survivalat 6 months;ORR, overallresponse rate; CTCAE v4, Common TerminologyCriteria for AdverseEvents, version 4.03; SAEs, seriousadverseevents; TEAEs, treatment-emergentadverseevents; MTD,maximum tolerated dose; DLT, dose-limitingtoxicities; RP2D, recommendedphase 2 dose; NCT, National Clinical Trial.

that among patients with MSI, there may be differences in the TME on the basis of hereditary or sporadic nature of the MMR deficiency [4]. These data have been recently confirmed at the Society for Gynecologic Oncology Annual Meeting on Women's Cancer by Ring and colleagues, who reported that EC related to LS has a stronger expression of PD-L1, in particular for LS caused by MSH6 loss [94].

For this reason, future clinical trials should stratify patients considering Lynch related and sporadic MSI-H tumor.

More recently, the European Society of Medical Oncology (ESMO) provided a practical guidance for MMR-deficiency testing in EC [95] underlying its emerging importance both to guide adjuvant treatment and to identify LS cases. Although there is not a general agreement on testing EC patients for LS, the above data suggest that MMR-deficiency could be predictive of response to immunotherapy and help clinicians in their therapeutic choices. At present, both MSI (pentaplex panel) and IHC are validated methods in EC testing $[96,97]$.

\section{Clinical settings and associations}

Considering its important role in EC, one of the most promising partners of checkpoint inhibitors is radiotherapy. In particular, as suggested for other malignancies, the so called out-of-the-field (abscopal) responses in patients receiving radiation therapy during immunotherapy may be relevant also in EC [98]. Another important direction of clinical research is represented by the association of chemotherapy and immune checkpoint inhibitors [99]. Although chemotherapies are believed to be immunosuppressive, when given at the right dose and sequence may provide a "priming" effect for the immune system. Trials have shown already that platinum based chemotherapy associated with immune checkpoint inhibitors is active in NSCLC [100]. Since chemotherapy (especially platinum based chemotherapy) is also active in $\mathrm{EC}$, it is likely to obtain similar results with the addition of a checkpoint inhibitor.

Considering other malignancies where the development of immune checkpoint inhibitors is more advanced (e.g. melanoma), there is no clear evidence 
suggesting a significant improvement in survival [69]. Accordingly, it is therefore more likely that patients with advanced endometrial cancer (stage III and IV) may benefit best from immune checkpoint inhibitors.

\section{CONCLUSIONS}

ECs have already proved to be an immunogenic diseases suggesting a potential role for checkpoints inhibitors in their treatment. As reviewed above, the TCGA classification is a step forward towards individualized therapies and should be considered in future clinical trials, to assess which subsets of EC patients are more likely to benefit from an immunotherapeutic approach. Further investigations should include the identification of which dominant immunosuppressive pathway characterizes each subtype in order to better identify reliable biomarkers of response. Future strategies will explore different clinical settings and combinations of chemo and radiotherapy with checkpoint inhibitors to boost immune response and improve patients outcomes.

\section{MATERIALS AND METHODS}

\section{Search strategy}

We conducted a search on Medline with Mesh keywords: endometrial cancer, endometrial carcinoma, endometrial neoplasm, endometrium cancer, endometrium carcinoma, and endometrium neoplasm. Moreover, the search strategy included terms for endometrial cancer matched with immunotherapy; tumor infiltrating lymphocytes (TILs); polymerase epsilon (POLE)-ultra-mutated; microsatellite instability (MSI); tumor-microenvironment; programmed death-1 (PD-1); programmed death-ligand 1 (PD-L1);cytotoxic T-lymphocyte-associated protein 4 (CTLA-4); the name of all checkpoint inhibitors discussed in the paper. The literature search was performed up to June 2017. Moreover had searched abstract books of conference proceedings between 2010 and 2017 to identify potentially eligible studies. With the same keywords we operated a search on clinicaltrials.gov.

\section{Selection criteria}

Retrevied articles were examined by all coauthors to assess their consistency with the aims of the article.

\section{Abbreviations}

Not applicable.

\section{Author contributions}

GM and GV conceived of the concept. EG, GM, SG, GG participated in data collection and interpretation, GV,
GM, and MA analyzed data and wrote the manuscript. All authors read and approved the final manuscript.

\section{ACKNOWLEDGMENTS}

Not applicable.

\section{CONFLICTS OF INTEREST}

The authors declare the absence of conflicts of interest

\section{FUNDING}

VALG_RIC_LOC_14_01 to GV.

\section{REFERENCES}

1. Siegel RL, Miller KD, Jemal A. Cancer statistics, 2016. CA Cancer J Clin. 2016; 66:7-30. https://doi.org/10.3322/ caac. 21332 .

2. J P, S F. Cancers of the female reproductive organs. In: Report WC, ed.: Lyon International Agency for Research on Cancer). 2014.

3. Network CGA. Comprehensive molecular characterization of human colon and rectal cancer. Nature. 2012; 487:330-7. https://doi.org/10.1038/nature11252.

4. Pakish JB, Zhang Q, Chen Z, Liang H, Chisholm G, Yuan Y, Mok SC, Broaddus RJ, Lu K, Yates MS. Immune microenvironment in microsatellite instable endometrial cancers: Hereditary or sporadic origin matters. Clin Cancer Res. 2017. https://doi.org/10.1158/1078-0432.CCR-16-2655.

5. Bethesda. http://seer.cancer.gov/csr/1975_2013/. (SEER web site. 2016).

6. Kokka F, Brockbank E, Oram D, Gallagher C, Bryant A. Hormonal therapy in advanced or recurrent endometrial cancer. Cochrane Database Syst Rev. 2010:CD007926. https://doi.org/10.1002/14651858.CD007926.pub2.

7. Humber CE, Tierney JF, Symonds RP, Collingwood M, Kirwan J, Williams C, Green JA. Chemotherapy for advanced, recurrent or metastatic endometrial cancer: a systematic review of Cochrane collaboration. Ann Oncol. 2007; 18:409-20. https://doi.org/10.1093/annonc/mdl417.

8. Espinosa I, D'Angelo E, Palacios J, Prat J. Mixed and Ambiguous Endometrial Carcinomas: A Heterogenous Group of Tumors With Different Clinicopathologic and Molecular Genetic Features. Am J Surg Pathol. 2016; 40:972-81. https://doi.org/10.1097/pas.0000000000000640.

9. Bokhman JV. Two pathogenetic types of endometrial carcinoma. Gynecol Oncol. 1983; 15:10-7.

10. Schlosshauer PW, Ellenson LH, Soslow RA. Betacatenin and E-cadherin expression patterns in high-grade endometrial carcinoma are associated with histological subtype. Mod Pathol. 2002; 15:1032-7. https://doi. org/10.1097/01.mp.0000028573.34289.04. 
11. Lax SF. Molecular genetic pathways in various types of endometrial carcinoma: from a phenotypical to a molecularbased classification. Virchows Arch. 2004; 444:213-23. https://doi.org/10.1007/s00428-003-0947-3.

12. Murali R, Soslow RA, Weigelt B. Classification of endometrial carcinoma: more than two types. Lancet Oncol. 2014; 15:e268-78. https://doi.org/10.1016/s14702045(13)70591-6.

13. Zighelboim I, Goodfellow PJ, Gao F, Gibb RK, Powell MA, Rader JS, Mutch DG. Microsatellite instability and epigenetic inactivation of MLH1 and outcome of patients with endometrial carcinomas of the endometrioid type. J Clin Oncol. 2007; 25:2042-8. https://doi.org/10.1200/ jco.2006.08.2107.

14. Kandoth C, Schultz N, Cherniack AD, Akbani R, Liu Y, Shen H, Robertson AG, Pashtan I, Shen R, Benz CC, Yau C, Laird PW, Ding L, et al. Integrated genomic characterization of endometrial carcinoma. Nature. 2013; 497:67-73. https:// doi.org/10.1038/nature12113.

15. Gargiulo P, Della Pepa C, Berardi S, Califano D, Scala S, Buonaguro L, Ciliberto G, Brauchli P, Pignata S. Tumor genotype and immune microenvironment in POLEultramutated and MSI-hypermutated Endometrial Cancers: New candidates for checkpoint blockade immunotherapy? Cancer Treat Rev. 2016; 48:61-8. https://doi.org/10.1016/j. ctrv.2016.06.008.

16. Stelloo E, Bosse T, Nout RA, MacKay HJ, Church DN, Nijman HW, Leary A, Edmondson RJ, Powell ME, Crosbie EJ, Kitchener HC, Mileshkin L, Pollock PM, et al. Refining prognosis and identifying targetable pathways for high-risk endometrial cancer; a TransPORTEC initiative. Mod Pathol. 2015; 28:836-44. https://doi.org/10.1038/ modpathol.2015.43.

17. McConechy MK, Talhouk A, Leung S, Chiu D, Yang W, Senz J, Reha-Krantz LJ, Lee CH, Huntsman DG, Gilks CB, McAlpine JN. Endometrial Carcinomas with POLE Exonuclease Domain Mutations Have a Favorable Prognosis. Clin Cancer Res. 2016; 22:2865-73. https://doi. org/10.1158/1078-0432.ccr-15-2233.

18. Meng B, Hoang LN, McIntyre JB, Duggan MA, Nelson GS, Lee CH, Köbel M. POLE exonuclease domain mutation predicts long progression-free survival in grade 3 endometrioid carcinoma of the endometrium. Gynecol Oncol. 2014; 134:15-9. https://doi.org/10.1016/j. ygyno.2014.05.006.

19. Church DN, Stelloo E, Nout RA, Valtcheva N, Depreeuw J, ter Haar N, Noske A, Amant F, Tomlinson IP, Wild PJ, Lambrechts D, Jürgenliemk-Schulz IM, Jobsen JJ, et al. Prognostic significance of POLE proofreading mutations in endometrial cancer. J Natl Cancer Inst. 2015; 107:402. https://doi.org/10.1093/jnci/dju402.

20. Espinosa I, Lee CH, D’Angelo E, Palacios J, Prat J. Undifferentiated and Dedifferentiated Endometrial Carcinomas With POLE Exonuclease Domain Mutations Have a Favorable Prognosis. Am J Surg Pathol. 2017. https://doi.org/10.1097/pas.0000000000000873.
21. Le Gallo M, Bell DW. The emerging genomic landscape of endometrial cancer. Clin Chem. 2014; 60:98-110. https:// doi.org/10.1373/clinchem.2013.205740.

22. Oda K, Stokoe D, Taketani Y, McCormick F. High frequency of coexistent mutations of PIK3CA and PTEN genes in endometrial carcinoma. Cancer Res. 2005; 65:10669-73. https://doi.org/10.1158/0008-5472.can-05-2620.

23. Diaz-Padilla I, Romero N, Amir E, Matias-Guiu X, Vilar E, Muggia F, Garcia-Donas J. Mismatch repair status and clinical outcome in endometrial cancer: a systematic review and metaanalysis. Crit Rev Oncol Hematol. 2013; 88:154-67. https:// doi.org/10.1016/j.critrevonc.2013.03.002.

24. Wilczyński M, Danielska J, Wilczyński J. An update of the classical Bokhman's dualistic model of endometrial cancer. Prz Menopauzalny. 2016; 15:63-8. https://doi.org/10.5114/ pm.2016.61186.

25. Hutchins G, Southward K, Handley K, Magill L, Beaumont C, Stahlschmidt J, Richman S, Chambers P, Seymour M, Kerr D, Gray R, Quirke P. Value of mismatch repair, KRAS, and BRAF mutations in predicting recurrence and benefits from chemotherapy in colorectal cancer. J Clin Oncol. 2011; 29:1261-70. https://doi.org/10.1200/JCO.2010.30.1366.

26. Talhouk A, McConechy MK, Leung S, Li-Chang HH, Kwon JS, Melnyk N, Yang W, Senz J, Boyd N, Karnezis AN, Huntsman DG, Gilks CB, McAlpine JN. A clinically applicable molecular-based classification for endometrial cancers. Br J Cancer. 2015; 113:299-310. https://doi. org/10.1038/bjc.2015.190.

27. Hussein YR, Weigelt B, Levine DA, Schoolmeester JK, Dao LN, Balzer BL, Liles G, Karlan B, Köbel M, Lee CH, Soslow RA. Clinicopathological analysis of endometrial carcinomas harboring somatic POLE exonuclease domain mutations. Mod Pathol. 2015; 28:505-14. https://doi. org/10.1038/modpathol.2014.143.

28. Wira CR, Fahey JV, Ghosh M, Patel MV, Hickey DK, Ochiel DO. Sex hormone regulation of innate immunity in the female reproductive tract: the role of epithelial cells in balancing reproductive potential with protection against sexually transmitted pathogens. Am J Reprod Immunol. 2010; 63:544-65. https://doi.org/10.1111/j.16000897.2010.00842.x.

29. Vanderstraeten A, Tuyaerts S, Amant F. The immune system in the normal endometrium and implications for endometrial cancer development. J Reprod Immunol. 2015; 109:7-16. https://doi.org/10.1016/j.jri.2014.12.006.

30. Longoria TC, Eskander RN. Immunotherapy in endometrial cancer - an evolving therapeutic paradigm. Gynecol Oncol Res Pract. 2015; 2:11. https://doi.org/10.1186/s40661-0150020-3.

31. Koebel CM, Vermi W, Swann JB, Zerafa N, Rodig SJ, Old LJ, Smyth MJ, Schreiber RD. Adaptive immunity maintains occult cancer in an equilibrium state. Nature. 2007; 450:903-7. https://doi.org/10.1038/nature06309.

32. Chen L, Flies DB. Molecular mechanisms of T cell costimulation and co-inhibition. Nat Rev Immunol. 2013; 13:227-42. https://doi.org/10.1038/nri3405. 
33. Bourla AB, Zamarin D. Immunotherapy: New Strategies for the Treatment of Gynecologic Malignancies. Oncology (Williston Park). 2016; 30:59-66, 9.

34. Keir ME, Butte MJ, Freeman GJ, Sharpe AH. PD-1 and its ligands in tolerance and immunity. Annu Rev Immunol. 2008; 26:677-704. https://doi.org/10.1146/annurev. immunol.26.021607.090331.

35. Boussiotis VA, Chatterjee P, Li L. Biochemical signaling of PD-1 on $\mathrm{T}$ cells and its functional implications. Cancer J. 2014; 20:265-71. https://doi.org/10.1097/ ppo.0000000000000059.

36. Francisco LM, Salinas VH, Brown KE, Vanguri VK, Freeman GJ, Kuchroo VK, Sharpe AH. PD-L1 regulates the development, maintenance, and function of induced regulatory T cells. J Exp Med. 2009; 206:3015-29. https:// doi.org/10.1084/jem.20090847.

37. Tumeh PC, Harview CL, Yearley JH, Shintaku IP, Taylor EJ, Robert L, Chmielowski B, Spasic M, Henry G, Ciobanu V, West AN, Carmona M, Kivork C, et al. PD-1 blockade induces responses by inhibiting adaptive immune resistance. Nature. 2014; 515:568-71. https://doi. org/10.1038/nature13954.

38. Topalian SL, Hodi FS, Brahmer JR, Gettinger SN, Smith DC, McDermott DF, Powderly JD, Carvajal RD, Sosman JA, Atkins MB, Leming PD, Spigel DR, Antonia SJ, et al. Safety, activity, and immune correlates of anti-PD-1 antibody in cancer. N Engl J Med. 2012; 366:2443-54. https://doi.org/10.1056/NEJMoa1200690.

39. Vanderstraeten A, Luyten C, Verbist G, Tuyaerts S, Amant F. Mapping the immunosuppressive environment in uterine tumors: implications for immunotherapy. Cancer Immunol Immunother. 2014; 63:545-57. https://doi.org/10.1007/ s00262-014-1537-8.

40. Herzog TJ, Arguello D, Reddy SK, Gatalica Z. PD-1 and PD-L1 expression in 1599 gynecological malignanicesimplications for immunotherapy. Gynecol Oncol. 2015; 137.

41. Mu CY, Huang JA, Chen Y, Chen C, Zhang XG. High expression of PD-L1 in lung cancer may contribute to poor prognosis and tumor cells immune escape through suppressing tumor infiltrating dendritic cells maturation. Med Oncol. 2011; 28:682-8. https://doi.org/10.1007/ s12032-010-9515-2.

42. Thompson RH, Dong H, Kwon ED. Implications of B7$\mathrm{H} 1$ expression in clear cell carcinoma of the kidney for prognostication and therapy. Clin Cancer Res. 2007; 13:709s-15s. https://doi.org/10.1158/1078-0432.ccr-06-1868.

43. Thompson RH, Dong H, Lohse CM, Leibovich BC, Blute ML, Cheville JC, Kwon ED. PD-1 is expressed by tumor-infiltrating immune cells and is associated with poor outcome for patients with renal cell carcinoma. Clin Cancer Res. 2007; 13:1757-61. https://doi.org/10.1158/1078-0432. ccr-06-2599.

44. Thompson RH, Kuntz SM, Leibovich BC, Dong H, Lohse CM, Webster WS, Sengupta S, Frank I, Parker AS,
Zincke H, Blute ML, Sebo TJ, Cheville JC, et al. Tumor B7$\mathrm{H} 1$ is associated with poor prognosis in renal cell carcinoma patients with long-term follow-up. Cancer Res. 2006; 66:3381-5. https://doi.org/10.1158/0008-5472.CAN-05-4303.

45. Huang Y, Zhang SD, McCrudden C, Chan KW, Lin Y, Kwok HF. The prognostic significance of PD-L1 in bladder cancer. Oncol Rep. 2015; 33:3075-84. https://doi.org/10.3892/ or.2015.3933.

46. Larkin J, Hodi FS, Wolchok JD. Combined Nivolumab and Ipilimumab or Monotherapy in Untreated Melanoma. N Engl J Med. 2015; 373:1270-1. https://doi.org/10.1056/ NEJMc1509660.

47. Tsao AS, Scagliotti GV, Bunn PA, Carbone DP, Warren GW, Bai C, de Koning HJ, Yousaf-Khan AU, McWilliams A, Tsao MS, Adusumilli PS, Rami-Porta R, Asamura H, et al. Scientific Advances in Lung Cancer 2015. J Thorac Oncol. 2016; 11:613-38. https://doi.org/10.1016/j. jtho.2016.03.012.

48. Ratta R, Zappasodi R, Raggi D, Grassi P, Verzoni E, Necchi A, Di Nicola M, Salvioni R, de Braud F, Procopio G. Immunotherapy advances in uro-genital malignancies. Crit Rev Oncol Hematol. 2016; 105:52-64. https://doi. org/10.1016/j.critrevonc.2016.06.012.

49. Howitt BE, Shukla SA, Sholl LM, Ritterhouse LL, Watkins JC, Rodig S, Stover E, Strickland KC, D'Andrea AD, Wu CJ, Matulonis UA, Konstantinopoulos PA. Association of Polymerase e-Mutated and Microsatellite-Instable Endometrial Cancers With Neoantigen Load, Number of Tumor-Infiltrating Lymphocytes, and Expression of PD-1 and PD-L1. JAMA Oncol. 2015; 1:1319-23. https://doi.org/10.1001/jamaoncol.2015.2151.

50. Piulats JM, Matias-Guiu X. Immunotherapy in Endometrial Cancer: In the Nick of Time. Clin Cancer Res. 2016; 22:5623-5. https://doi.org/10.1158/1078-0432.ccr-16-1820.

51. Lee N, Zakka LR, Mihm MC, Schatton T. Tumourinfiltrating lymphocytes in melanoma prognosis and cancer immunotherapy. Pathology. 2016; 48:177-87. https://doi. org/10.1016/j.pathol.2015.12.006.

52. Sudo T, Nishida R, Kawahara A, Saisho K, Mimori K, Yamada A, Mizoguchi A, Kadoya K, Matono S, Mori N, Tanaka T, Akagi Y. Clinical Impact of Tumor-Infiltrating Lymphocytes in Esophageal Squamous Cell Carcinoma. Ann Surg Oncol. 2017. https://doi.org/10.1245/s10434-0175796-4.

53. Stanton SE, Disis ML. Clinical significance of tumorinfiltrating lymphocytes in breast cancer. J Immunother Cancer. 2016; 4:59. https://doi.org/10.1186/s40425-0160165-6.

54. Duong CP, Yong CS, Kershaw MH, Slaney CY, Darcy PK. Cancer immunotherapy utilizing gene-modified T cells: From the bench to the clinic. Mol Immunol. 2015. https:// doi.org/10.1016/j.molimm.2014.12.009.

55. Zhang L, Conejo-Garcia JR, Katsaros D, Gimotty PA, Massobrio M, Regnani G, Makrigiannakis A, Gray H, Schlienger K, Liebman MN, Rubin SC, Coukos G. 
Intratumoral T cells, recurrence, and survival in epithelial ovarian cancer. N Engl J Med. 2003; 348:203-13. https:// doi.org/10.1056/NEJMoa020177.

56. Sato E, Olson SH, Ahn J, Bundy B, Nishikawa H, Qian F, Jungbluth AA, Frosina D, Gnjatic S, Ambrosone C, Kepner J, Odunsi T, Ritter G, et al. Intraepithelial CD8+ tumor-infiltrating lymphocytes and a high CD8+/regulatory $\mathrm{T}$ cell ratio are associated with favorable prognosis in ovarian cancer. Proc Natl Acad Sci USA. 2005; 102:18538-43. https://doi.org/10.1073/pnas.0509182102.

57. de Jong RA, Leffers N, Boezen HM, ten Hoor KA, van der Zee AG, Hollema H, Nijman HW. Presence of tumorinfiltrating lymphocytes is an independent prognostic factor in type I and II endometrial cancer. Gynecol Oncol. 2009; 114:105-10. https://doi.org/10.1016/j.ygyno.2009.03.022.

58. Yamagami W, Susumu N, Tanaka H, Hirasawa A, Banno K, Suzuki N, Tsuda H, Tsukazaki K, Aoki D. Immunofluorescence-detected infiltration of CD4+FOXP3+ regulatory $\mathrm{T}$ cells is relevant to the prognosis of patients with endometrial cancer. Int J Gynecol Cancer. 2011; 21:1628-34. https://doi.org/10.1097/IGC.0b013e31822c271f.

59. Brunner A, Hinterholzer S, Riss P, Heinze G, Brustmann H. Immunoexpression of $\mathrm{B} 7-\mathrm{H} 3$ in endometrial cancer: relation to tumor T-cell infiltration and prognosis. Gynecol Oncol. 2012; 124:105-11. https://doi.org/10.1016/j. ygyno.2011.09.012.

60. Kübler K, Ayub TH, Weber SK, Zivanovic O, Abramian A, Keyver-Paik MD, Mallmann MR, Kaiser C, Serçe NB, Kuhn W, Rudlowski C. Prognostic significance of tumorassociated macrophages in endometrial adenocarcinoma. Gynecol Oncol. 2014; 135:176-83. https://doi. org/10.1016/j.ygyno.2014.08.028.

61. Chang WC, Li CH, Huang SC, Chang DY, Chou LY, Sheu BC. Clinical significance of regulatory $\mathrm{T}$ cells and $\mathrm{CD} 8+$ effector populations in patients with human endometrial carcinoma. Cancer. 2010; 116:5777-88. https:// doi.org/10.1002/cncr.25371.

62. Eggink FA, Van Gool IC, Leary A, Pollock PM, Crosbie EJ, Mileshkin L, Jordanova ES, Adam J, Freeman-Mills L, Church DN, Creutzberg CL, De Bruyn M, Nijman HW, et al. Immunological profiling of molecularly classified high-risk endometrial cancers identifies POLE-mutant and microsatellite unstable carcinomas as candidates for checkpoint inhibition. Oncoimmunology. 2017; 6:e1264565. https://doi.org/10.1080/2162402X.2016.1264565.

63. Brahmer J, Reckamp KL, Baas P, Crinò L, Eberhardt WE, Poddubskaya E, Antonia S, Pluzanski A, Vokes EE, Holgado E, Waterhouse D, Ready N, Gainor J, et al. Nivolumab versus Docetaxel in Advanced SquamousCell Non-Small-Cell Lung Cancer. N Engl J Med. 2015; 373:123-35. https://doi.org/10.1056/NEJMoa1504627.

64. Reck M, Rodríguez-Abreu D, Robinson AG, Hui R, Csőszi T, Fülöp A, Gottfried M, Peled N, Tafreshi A, Cuffe S, O’Brien M, Rao S, Hotta K, et al. Pembrolizumab versus Chemotherapy for PD-L1-Positive Non-Small-Cell
Lung Cancer. N Engl J Med. 2016; 375:1823-33. https:// doi.org/10.1056/NEJMoa1606774.

65. Ribas A, Hamid O, Daud A, Hodi FS, Wolchok JD, Kefford R, Joshua AM, Patnaik A, Hwu WJ, Weber JS, Gangadhar TC, Hersey P, Dronca R, et al. Association of Pembrolizumab With Tumor Response and Survival Among Patients With Advanced Melanoma. JAMA. 2016; 315:1600-9. https://doi.org/10.1001/jama.2016.4059.

66. Ribas A, Puzanov I, Dummer R, Schadendorf D, Hamid O, Robert C, Hodi FS, Schachter J, Pavlick AC, Lewis KD, Cranmer LD, Blank CU, O'Day SJ, et al. Pembrolizumab versus investigator-choice chemotherapy for ipilimumabrefractory melanoma (KEYNOTE-002): a randomised, controlled, phase 2 trial. Lancet Oncol. 2015; 16:908-18. https://doi.org/10.1016/s1470-2045(15)00083-2.

67. Robert C, Schachter J, Long GV, Arance A, Grob JJ, Mortier L, Daud A, Carlino MS, McNeil C, Lotem M, Larkin J, Lorigan P, Neyns B, et al. Pembrolizumab versus Ipilimumab in Advanced Melanoma. N Engl J Med. 2015; 372:2521-32. https://doi.org/10.1056/NEJMoa1503093.

68. Weber JS, D'Angelo SP, Minor D, Hodi FS, Gutzmer R, Neyns B, Hoeller C, Khushalani NI, Miller WH, Lao CD, Linette GP, Thomas L, Lorigan P, et al. Nivolumab versus chemotherapy in patients with advanced melanoma who progressed after anti-CTLA-4 treatment (CheckMate 037): a randomised, controlled, open-label, phase 3 trial. Lancet Oncol. 2015; 16:375-84. https://doi.org/10.1016/s14702045(15)70076-8.

69. Robert C, Long GV, Brady B, Dutriaux C, Maio M, Mortier L, Hassel JC, Rutkowski P, McNeil C, KalinkaWarzocha E, Savage KJ, Hernberg MM, Lebbé C, et al. Nivolumab in previously untreated melanoma without BRAF mutation. N Engl J Med. 2015; 372:320-30. https:// doi.org/10.1056/NEJMoa1412082.

70. Motzer RJ, Hutson TE, Ren M, Dutcus C, Larkin J. Independent assessment of lenvatinib plus everolimus in patients with metastatic renal cell carcinoma. Lancet Oncol. 2016; 17:e4-5. https://doi.org/10.1016/s14702045(15)00543-4.

71. Balar AV, Galsky MD, Rosenberg JE, Powles T, Petrylak DP, Bellmunt J, Loriot Y, Necchi A, Hoffman-Censits J, PerezGracia JL, Dawson NA, van der Heijden MS, Dreicer R, et al. Atezolizumab as first-line treatment in cisplatinineligible patients with locally advanced and metastatic urothelial carcinoma: a single-arm, multicentre, phase 2 trial. Lancet. 2017; 389:67-76. https://doi.org/10.1016/ S0140-6736(16)32455-2.

72. Rosenberg JE, Hoffman-Censits J, Powles T, van der Heijden MS, Balar AV, Necchi A, Dawson N, O’Donnell PH, Balmanoukian A, Loriot Y, Srinivas S, Retz MM, Grivas P, et al. Atezolizumab in patients with locally advanced and metastatic urothelial carcinoma who have progressed following treatment with platinum-based chemotherapy: a single-arm, multicentre, phase 2 trial. Lancet. 2016; 387:190920. https://doi.org/10.1016/s0140-6736(16)00561-4. 
73. Ansell SM, Lesokhin AM, Borrello I, Halwani A, Scott EC, Gutierrez M, Schuster SJ, Millenson MM, Cattry D, Freeman GJ, Rodig SJ, Chapuy B, Ligon AH, et al. PD-1 blockade with nivolumab in relapsed or refractory Hodgkin's lymphoma. N Engl J Med. 2015; 372:311-9. https://doi.org/10.1056/NEJMoa1411087.

74. Armand P, Shipp MA, Ribrag V, Michot JM, Zinzani PL, Kuruvilla J, Snyder ES, Ricart AD, Balakumaran A, Rose S, Moskowitz CH. Programmed Death-1 Blockade With Pembrolizumab in Patients With Classical Hodgkin Lymphoma After Brentuximab Vedotin Failure. J Clin Oncol. 2016. https://doi.org/10.1200/jco.2016.67.3467.

75. Le DT, Uram JN, Wang H, Bartlett BR, Kemberling H, Eyring AD, Skora AD, Luber BS, Azad NS, Laheru D, Biedrzycki B, Donehower RC, Zaheer A, et al. PD-1 Blockade in Tumors with Mismatch-Repair Deficiency. N Engl J Med. 2015; 372:2509-20. https://doi.org/10.1056/ NEJMoa1500596.

76. Ott PA, Bang YJ, Berton-Rigaud D, Elez E, Pishvaian MJ, Rugo HS, Puzanov I, Mehnert JM, Aung KL, Lopez J, Carrigan M, Saraf S, Chen M, et al. Safety and Antitumor Activity of Pembrolizumab in Advanced Programmed Death Ligand 1-Positive Endometrial Cancer: Results From the KEYNOTE-028 Study. J Clin Oncol. 2017; JCO2017725952. https://doi.org/10.1200/jco.2017.72.5952.

77. Mehnert JM, Panda A, Zhong H, Hirshfield K, Damare S, Lane K, Sokol L, Stein MN, Rodriguez-Rodriquez L, Kaufman HL, Ali S, Ross JS, Pavlick DC, et al. Immune activation and response to pembrolizumab in POLE-mutant endometrial cancer. J Clin Invest. 2016; 126:2334-40. https://doi.org/10.1172/jci84940.

78. Makker V, Rasco DW, Dutcus EC, Stepan DE, Li D, Schmidt EW, Shumaker RC, Taylor MH. A phase Ib/II trial of lenvatinib (LEN) plus pembrolizumab (Pembro) in patients (Pts) with endometrial carcinoma. J Clin Oncol. 2017.

79. Santin AD, Bellone S, Buza N, Choi J, Schwartz PE, Schlessinger J, Lifton RP. Regression of ChemotherapyResistant Polymerase $\varepsilon$ (POLE) Ultra-Mutated and MSH6 Hyper-Mutated Endometrial Tumors with Nivolumab. Clin Cancer Res. 2016; 22:5682-7. https://doi.org/10.1158/10780432.ccr-16-1031.

80. Fleming GF, Emens LA, Eder JP, Hamilton EP, Liu JF, Liu B, Molinero L, Fasso M, O'Hear C, Braiteh FS. Clinical activity, sefety and biomarker results from a phase Ia study of atezolizumab (atezo)in advanced/recurrent endometrial cancer(rEC). J Clin Oncol. 2017.

81. Konstantinopoulos PA, Liu JF, Barry WT, Krasner CN, Buss MK, Birrer MJ, Farooq S, Campos SM, Stover E, Schumer S, Wright AA, Curtis J, Peralta A, et al. Phase 2, two-group, two-stage, open-label study of avelumab in patients with microsatellite stable, microsatellite instable and POLE-mutated recurrent or persistent endometrial cancer. J Clin Oncol. 2017.

82. Hodi FS, O'Day SJ, McDermott DF, Weber RW, Sosman JA, Haanen JB, Gonzalez R, Robert C, Schadendorf D,
Hassel JC, Akerley W, van den Eertwegh AJ, Lutzky J, et al. Improved survival with ipilimumab in patients with metastatic melanoma. N Engl J Med. 2010; 363:711-23. https://doi.org/10.1056/NEJMoa1003466.

83. Snyder A, Makarov V, Merghoub T, Yuan J, Zaretsky JM, Desrichard A, Walsh LA, Postow MA, Wong P, Ho TS, Hollmann TJ, Bruggeman C, Kannan K, et al. Genetic basis for clinical response to CTLA-4 blockade in melanoma. N Engl J Med. 2014; 371:2189-99. https://doi.org/10.1056/ NEJMoa1406498.

84. Webb JR, Milne K, Kroeger DR, Nelson BH. PD-L1 expression is associated with tumor-infiltrating $\mathrm{T}$ cells and favorable prognosis in high-grade serous ovarian cancer. Gynecol Oncol. 2016; 141:293-302. https://doi. org/10.1016/j.ygyno.2016.03.008.

85. Taube JM, Klein A, Brahmer JR, Xu H, Pan X, Kim JH, Chen L, Pardoll DM, Topalian SL, Anders RA. Association of PD-1, PD-1 ligands, and other features of the tumor immune microenvironment with response to anti-PD-1 therapy. Clin Cancer Res. 2014; 20:5064-74. https://doi. org/10.1158/1078-0432.ccr-13-3271.

86. Rizvi NA, Hellmann MD, Snyder A, Kvistborg P, Makarov V, Havel JJ, Lee W, Yuan J, Wong P, Ho TS, Miller ML, Rekhtman N, Moreira AL, et al. Cancer immunology. Mutational landscape determines sensitivity to PD-1 blockade in non-small cell lung cancer. Science. 2015; 348:124-8. https://doi.org/10.1126/science.aaa1348.

87. Heemskerk B, Kvistborg P, Schumacher TN. The cancer antigenome. EMBO J. 2013; 32:194-203. https://doi. org/10.1038/emboj.2012.333.

88. Aguiar PN, Santoro IL, Tadokoro H, de Lima Lopes G, Filardi BA, Oliveira P, Mountzios G, de Mello RA. The role of PD-L1 expression as a predictive biomarker in advanced non-small-cell lung cancer: a network meta-analysis. Immunotherapy. 2016; 8:479-88. https://doi.org/10.2217/ imt-2015-0002.

89. Zaretsky JM, Garcia-Diaz A, Shin DS, Escuin-Ordinas H, Hugo W, Hu-Lieskovan S, Torrejon DY, Abril-Rodriguez G, Sandoval S, Barthly L, Saco J, Homet Moreno B, Mezzadra R, et al. Mutations Associated with Acquired Resistance to PD-1 Blockade in Melanoma. N Engl J Med. 2016; 375:819-29. https://doi.org/10.1056/NEJMoa1604958.

90. Shin DS, Zaretsky JM, Escuin-Ordinas H, GarciaDiaz A, Hu-Lieskovan S, Kalbasi A, Grasso CS, Hugo W, Sandoval S, Torrejon DY, Palaskas N, Rodriguez GA, Parisi G, et al. Primary Resistance to PD-1 Blockade Mediated by JAK1/2 Mutations. Cancer Discov. 2017; 7:188-201. https://doi.org/10.1158/2159-8290.cd-16-1223.

91. Roh W, Chen PL, Reuben A, Spencer CN, Prieto PA, Miller JP, Gopalakrishnan V, Wang F, Cooper ZA, Reddy SM, Gumbs C, Little L, Chang Q, et al. Integrated molecular analysis of tumor biopsies on sequential CTLA4 and PD-1 blockade reveals markers of response and resistance. Sci Transl Med. 2017; 9. https://doi.org/10.1126/ scitranslmed.aah3560. 
92. van Gool IC, Eggink FA, Freeman-Mills L, Stelloo E, Marchi E, de Bruyn M, Palles C, Nout RA, de Kroon CD, Osse EM, Klenerman P, Creutzberg CL, Tomlinson IP, et al. POLE Proofreading Mutations Elicit an Antitumor Immune Response in Endometrial Cancer. Clin Cancer Res. 2015; 21:3347-55. https://doi.org/10.1158/1078-0432.ccr-15-0057.

93. Shukla SA, Howitt BE, Wu CJ, Konstantinopoulos PA. Predicted neoantigen load in non-hypermutated endometrial cancers: Correlation with outcome and tumor-specific genomic alterations. Gynecol Oncol Rep. 2017; 19:42-5. https://doi.org/10.1016/j.gore.2016.12.009.

94. Sloan EA, Ring KL, Willis BC, Modesitt SC, Mills AM. PD-L1 Expression in Mismatch Repair-deficient Endometrial Carcinomas, Including Lynch Syndromeassociated and MLH1 Promoter Hypermethylated Tumors. Am J Surg Pathol. 2017; 41:326-33. https://doi. org/10.1097/pas.0000000000000783.

95. Stelloo E, Jansen AML, Osse EM, Nout RA, Creutzberg CL, Ruano D, Church DN, Morreau H, Smit VTHB, van Wezel T, Bosse T. Practical guidance for mismatch repairdeficiency testing in endometrial cancer. Ann Oncol. 2017; 28:96-102. https://doi.org/10.1093/annonc/mdw542.

96. McConechy MK, Talhouk A, Li-Chang HH, Leung S, Huntsman DG, Gilks CB, McAlpine JN. Detection of DNA mismatch repair (MMR) deficiencies by immunohistochemistry can effectively diagnose the microsatellite instability (MSI) phenotype in endometrial carcinomas. Gynecol Oncol. 2015; 137:306-10. https://doi. org/10.1016/j.ygyno.2015.01.541.

97. Watkins JC, Nucci MR, Ritterhouse LL, Howitt BE, Sholl LM. Unusual Mismatch Repair Immunohistochemical Patterns in Endometrial Carcinoma. Am J Surg Pathol. 2016; 40:909-16. https://doi.org/10.1097/pas.0000000000000663.

98. Pilones KA, Vanpouille-Box C, Demaria S. Combination of radiotherapy and immune checkpoint inhibitors. Semin Radiat Oncol. 2015; 25:28-33. https://doi.org/10.1016/j. semradonc.2014.07.004.

99. Soliman HH. nab-Paclitaxel as a potential partner with checkpoint inhibitors in solid tumors. Onco Targets Ther. 2017; 10:101-12. https://doi.org/10.2147/OTT.S122974.

100. Rizvi NA, Hellmann MD, Brahmer JR, Juergens RA, Borghaei H, Gettinger S, Chow LQ, Gerber DE, Laurie SA, Goldman JW, Shepherd FA, Chen AC, Shen Y, et al. Nivolumab in Combination With Platinum-Based Doublet Chemotherapy for First-Line Treatment of Advanced NonSmall-Cell Lung Cancer. J Clin Oncol. 2016; 34:2969-79. https://doi.org/10.1200/JCO.2016.66.9861. 